\title{
The Effect of Different Rates of Prohexadione-Calcium and Girdling on Shoot Growth and Fruit Quality when Applied to Different Pear Cultivars
}

\author{
J.J. Meintjes, P. Stassen and K.I. Theron \\ Department of Horticultural Science \\ University of Stellenbosch, Matieland \\ South Africa
}

Keywords: fruit size, girdling, prohexadione-Ca, Pyrus communis L., shoot growth

\begin{abstract}
Prohexadione-Calcium (P-Ca) is a promising new shoot growth retardant that is already registered on apples in North America (Apogee ${ }^{\circledR}$ ) and in Europe $\left(\right.$ Regalis $\left.^{\circledR}\right)$. This gibberellin biosynthesis inhibitor with limited persistence and low toxicity was tested on five Pyrus communis cultivars: 'Rosemarie', 'Flamingo', 'Early Bon Chretien', 'Packham's Triumph' and 'Forelle'. P-Ca was able to reduce shoot growth in all of the cultivars, but there was a marked difference in sensitivity towards different rates of P-Ca between the different cultivars. Fruit set was improved in 'Rosemarie', 'Forelle' and 'Early Bon Chretien', which led to a decrease in final fruit size of 'Rosemarie'. P-Ca caused a decrease in return bloom in 'Packham's Triumph' and 'Forelle'. Girdling only reduced shoot growth in 'Forelle' but did not improve fruit set in any of the cultivars. Girdling improved final fruit weight of 'Flamingo', increased fruit length in 'Early Bon Chretien' and increased return bloom in all of the cultivars except 'Packham's Triumph'. The five cultivars are categorised according to their sensitivity towards P-Ca: 'Rosemarie' > 'Flamingo' = 'Early Bon Chretien' = 'Packham's Triumph' > 'Forelle'.
\end{abstract}

\section{INTRODUCTION}

Controlling excessive vegetative growth in fruit trees is very important (Costa et al., 2002; Forshey and Elfving, 1989; Williams, 1984) as it is a strong sink that competes with the fruit on the tree. This competition is at its strongest during the first 50 days after full bloom when shoot growth is very rapid (Byers and Yoder, 1999; Elfving et al. 2002) and coincides with the cell division stage of fruit growth. This results in a decrease in the number of cells in the fruit and, therefore, fruit size (Cowan et al., 2001; Yamaguchi et al., 2002). Excessive shoot growth also has a negative effect on fruit quality, yield and pest control (Greene, 1999; Miller and Tworkoski, 2003). Shading caused by excessive shoot growth has a negative effect on flower bud induction and the quality of the return bloom (Greene, 1999; Miller and Tworkoski, 2003). One of the main methods to control shoot growth is pruning. Pruning, however, is a very expensive, labour intensive and time-consuming management practice (Byers and Yoder, 1999). Other control measures have been used e.g. ethephon applications, summer pruning, root pruning and dwarfing rootstocks, but all have negative side effects (Greene, 1999). Girdling is also a practice used in pear orchards to control shoot growth, increase fruit set and improve fruit quality (Ingels, 2002; Miller and Tworkoski, 2003; Wilton, 2000). Girdling affects assimilate partitioning and the flow of plant hormones and nutrients throughout the tree (Miller and Tworkoski, 2003).

As gibberellins (GA) have been implicated in stem elongation (Owens and Stover, 1999) researchers have been looking at GA biosynthesis inhibitors to counteract these and thus reduce shoot growth (Miller, 2002; Unrath, 1999). Although many of these compounds inhibit shoot elongation (e.g. chlormequat, daminozide) their persistence in the tree is a big disadvantage (Owens and Stover, 1999).

Prohexadione-calcium [(P-Ca); BAS-125 (3-oxido-4-propionyl-5-oxo-3cyclohexene-carboxylate)] is a GA biosynthesis inhibitor with low toxicity and limited persistence (Owens and Stover, 1999). The application of P-Ca reduces levels of $\mathrm{GA}_{1}$ 
(highly active) and causes the accumulation of its precursor $\mathrm{GA}_{20}$ (inactive) (Evans et al., 1999). P-Ca is registered on apples as Apogee ${ }^{\circledR}$ in North America and as Regalis ${ }^{\circledR}$ in Europe (Miller and Tworkoski, 2003). After good results in previous trials on pears (Basak and Rademacher, 2000; Costa et al., 2002; Theron et al., 2002), the response of five different pear cultivars to $\mathrm{P}-\mathrm{Ca}$ will be presented in this paper.

\section{MATERIALS AND METHODS}

\section{Plant Material}

The trials were conducted in the 2002/03 season in commercial orchards on La Plaisante Estate in the Wolseley area in the Western Cape, South Africa $\left(33^{\circ} 25^{\prime} \mathrm{S}\right.$ $19^{\circ} 12^{\prime} \mathrm{E}$; ca. 270 m.a.s.1.; mediterranean climate). Descriptions of the orchards are presented in Table 1.

\section{Treatments and Experimental Design}

The control treatment was unsprayed and ungirdled. The girdling treatment entailed a cut through the bark approximately $30 \mathrm{~cm}$ above the ground using the chain of a chain saw, approximately 2 weeks after full bloom. The wettable granular formulation BAS $12510 \mathrm{~W}$ was applied at high volume with a handset mounted on the back of a pickup truck. This formulation contains $10 \%(\mathrm{w}: \mathrm{w})$ of $\mathrm{P}-\mathrm{Ca}$ as active ingredient. The rates and timing of $\mathrm{P}-\mathrm{Ca}$ treatments were the same for all the cultivars and are summarised in Table 2. In all of the P-Ca treatments the surfactant 'Dash' was added at a rate of $40 \mathrm{ml} .100 \mathrm{l}^{-1}$ water. All of the applications were done in the late afternoon when conditions for absorption were favourable and temperatures were decreasing.

A randomised complete block design was used as trial layout with 10 single tree replications and 5 treatments each (Table 2).

\section{Data Collected}

The following data were collected: (1) The fruit set was determined after the natural fruit drop period by counting fruit hand thinned from each individual tree. (2) At harvest the fruit of each tree were weighed to determine the yield for each treatment. The trunk circumference of each tree was measured. (3) At harvest 25 fruit per tree were randomly sampled and destructively analysed. The length, diameter, weight, firmness, number of developed seeds and the number of seeds with aborted embryos of the fruit were determined. (4) Twenty one-year old shoots per tree were measured on 19 March 2003 to determine the final shoot growth. (5) The return bloom was monitored in 2003. The number of vegetative and reproductive buds on two tagged branches were counted and the reproductive buds expressed as a percentage of the total number of buds. Only the terminal buds were counted on one-year old shoots.

The General Linear Models (GLM) procedure of the Statistical Analyses System (SAS) was used to analyse the data.

\section{RESULTS}

\section{Shoot Growth}

In 'Rosemarie', all the $\mathrm{P}-\mathrm{Ca}$ treatments reduced shoot growth significantly compared to the control and the girdled trees $(\mathrm{P}=0.0050)$ (Table 3). This reduction in shoot growth also occurred in the case of 'Early Bon Chretien' $(\mathrm{P}=0.0030)$, 'Flamingo' $(\mathrm{P}=0.0001)$, 'Packham's Triumph' $(\mathrm{P}=0.0001)$ and 'Forelle $(\mathrm{P}=0.0001)$ (Table 3$)$. A lack in the response of trees to girdling occurred in all the cultivars except in 'Forelle'.

For 'Rosemarie' and 'Forelle' there was no significant difference in shoot growth reduction between the different P-Ca treatments. In 'Early Bon Chretien' the $250 \mathrm{mg} . \mathrm{l}^{-1}$ treatment had significantly less shoot growth than the other P-Ca treatments. In 'Flamingo' the $2 \times 125 \mathrm{mg} .1^{-1}$ treatment had significantly less shoot growth than the 125 mg. $1^{-1}$ treatment. In 'Packham's Triumph', the $250 \mathrm{mg} . \mathrm{l}^{-1} \mathrm{P}-\mathrm{Ca}$ treatment had 
significantly less shoot growth than the $125 \mathrm{mg} . \mathrm{l}^{-1}$ treatment.

\section{Fruit Set}

$\mathrm{P}-\mathrm{Ca}$ caused an increase in the fruit set/cluster on the tagged branches for 'Rosemarie' $(\mathrm{P}=0.0136)$ and 'Forelle' $(\mathrm{P}=0.0207)$ (data not presented). The number of fruit thinned by hand indicated that the $\mathrm{P}-\mathrm{Ca}$ treatments improved fruit set significantly on 'Rosemarie' $(\mathrm{P}=0.0004)$ (Table 4) and 'Early Bon Chretien' $(\mathrm{P}=0.0175)$ (Table 4), but there was no significant improvement in the fruit set of 'Forelle' (Table 4). There was no significant difference in the fruit set of 'Flamingo' or 'Packham's Triumph' (data not presented). Girdling was not able to improve the fruit set in any of the cultivars.

\section{Fruit Weight, Quality and Yield}

The mean fruit weight of P-Ca treated trees was significantly lower for 'Rosemarie' ( $\mathrm{P}=0.0001)$ (Table 5). There was no significant difference in the mean fruit weight between the control and P-Ca treatments of 'Early Bon Chretien' (data not presented) and 'Flamingo' (Table 5). The P-Ca treated trees of 'Flamingo' had fruit with a significantly shorter fruit length $(\mathrm{P}=0.0001)$. There was no significant difference in the fruit weight of 'Packham's Triumph' (Table 5), 'Early Bon Chretien' and 'Forelle' (data not presented) between the treatments.

Girdling improved the mean fruit weight of 'Flamingo' compared to the control and P-Ca treated trees (Table 5). Girdling also improved the fruit length of 'Early Bon Chretien' compared to the control and P-Ca treated trees (data not presented). Girdling had no significant effect on the fruit size of 'Rosemarie', 'Packham's Triumph' (Table 5) or 'Forelle' (data not presented).

There was no difference in fruit firmness, number of developed seeds and seeds with aborted embryos per fruit, or the yield ( $\mathrm{kg}$ harvested / $\mathrm{cm}$ trunk circumference) between any of the treatments for any of the cultivars (data not presented).

\section{Return Bloom}

For all of the cultivars, the return bloom was significantly higher in the girdled treatment than any of the other treatments (Table 6), except for 'Packham's Triumph' where it was not significantly higher than the control. No significant difference was found between the control and P-Ca treatments for 'Early Bon Chretien', 'Flamingo' and 'Rosemarie'. For 'Early Bon Chretien', the $250 \mathrm{mg} \cdot \mathrm{l}^{-1} \mathrm{P}-\mathrm{Ca}$ treatment had a significantly lower percentage of reproductive buds than the $125 \mathrm{mg} . \mathrm{l}^{-1}$ and $2 \times 125 \mathrm{mg} \cdot \mathrm{l}^{-1} \mathrm{P}-\mathrm{Ca}$ treatments. The P-Ca treatments on 'Forelle' and 'Packham's Triumph' significantly reduced the number of reproductive buds $(\mathrm{P}=0.0201$ and $\mathrm{P}=0.0004$, respectively), however there was no significant difference between the different P-Ca treatments.

\section{DISCUSSION}

P-Ca reduced shoot growth significantly in all of the cultivars. According to the data, pear cultivars could be separated into three groups according to their sensitivity to different rates of P-Ca. The first category responded well at low rates of P-Ca. 'Rosemarie' is an example of such a cultivar where an increase in P-Ca concentration did not have better shoot growth control (Table 3). Theron et al. (2002) had similar results with 'Rosemarie'.

The second category consisted of cultivars that responded well to higher rates of P-Ca. 'Flamingo', 'Early Bon Chretien' and 'Packham's Triumph' fell into this category (Table 3). Costa et al. (2001) found that four P-Ca applications at $100 \mathrm{mg} . \mathrm{l}^{-1}$ reduced shoot growth significantly while four applications at $50 \mathrm{mg} \cdot \mathrm{l}^{-1}$ did not significantly reduce shoot growth of 'Abbe Fetel' pears. Applying this higher rate of $\mathrm{P}-\mathrm{Ca}$ as a split application i.e. $2 \times 125 \mathrm{mg} . \mathrm{l}^{-1}$ rather than a single $250 \mathrm{mg} .1^{-1}$ treatment is advisable. The $250 \mathrm{mg} . \mathrm{l}^{-1}$ treatment caused more re-growth later in the season after harvest (data not presented), especially in 'Early Bon Chretien'. This second growth flush is hard to explain (Elfving et al., 2003) and an effective control strategy is still unclear. Elfving et 
al. (2002) found four different shoot growth patterns in different pear cultivars. Three of these patterns consisted of more than one growth flush. Multiple applications (even 3 or more) may be needed (Elfving et al., 2003) to control this second growth flush. The relationship between the rate of the initial application and the second growth flush should be investigated.

The last category was hard to control even at high rates of P-Ca. 'Forelle' falls into this category (Table 3). Although shoot growth control was obtained, the total amount of shoot growth was still much more than in any of the other cultivars (Fig. 1).

In previous work Smit (2002) had similar results with different rates of P-Ca and the response of different cultivars. From her work it seems that 'Golden Russet Bosc' also falls into the second category. Basak and Rademacher (2000) also found that 'Conference' only had shoot growth control at the highest concentration (225 mg. $\left.{ }^{-1}\right)$ of P$\mathrm{Ca}$ that was applied.

$\mathrm{P}-\mathrm{Ca}$ had a negative influence on fruit size in 'Rosemarie' and 'Early Bon Chretien'. It should be noted that 'Forelle' was the most difficult cultivar in which to control shoot growth and P-Ca did not cause an increase in the fruit set (according to the number and weight of fruit thinned by hand) or a decrease in fruit size. In 'Packham's Triumph' there was no increase in fruit set and no decrease in fruit size. The decrease in fruit size seems to be directly correlated with an increase in fruit set of the P-Ca treatments. Sugar et al. (2002) had similar results where P-Ca treatments resulted in smaller average fruit size of 'Bartlett' pears and suggested that it was due to an increased fruit set. Costa et al. (2001) found that P-Ca applications increased fruit size in 'Abbe Fetel' pears. Greene (1999) found that P-Ca increased fruit set in apples. Higher fruit set causes more competition in the critical cell division stage. Instead of reducing competition by reducing shoot growth, competition is increased because of more fruit on the tree. The increased fruit set is an indication that more assimilates are available for fruit growth when shoot growth is reduced in the cell division stage. This can be managed better with an earlier hand thinning or even a chemical thinner. It should be investigated if this will be possible, because of the natural fruit drop period that still has to follow. This might cause over thinning of trees.

Sugar et al. (2002) also found that P-Ca treatments led to a considerable decline in return bloom in 'Beurré Bosc', 'Anjou', 'Red Anjou' and 'Bartlett'. They also found a difference in sensitivity to the reduction in return bloom with 'Beurré Bosc' being the most sensitive and 'Bartlett' the least sensitive. The reduction in return bloom did not significantly affect cropping. In these trials we found a similar difference in sensitivity in return bloom between cultivars towards the concentration and timing of P-Ca applications. Further trials with rates and timing on different cultivars are needed to determine which $\mathrm{P}-\mathrm{Ca}$ applications provide good shoot growth control without any adverse effects.

Girdling did not increase fruit set in any of the cultivars. Girdling only had significantly less shoot growth in 'Forelle'. Theron et al. (2002) also found that girdling was not effective in controlling shoot growth in 'Rosemarie'. In all of the cultivars the girdled trees had the biggest average fruit size. This phenomenon is hard to explain and must be investigated in more detail. Girdling increased return bloom in all of the cultivars except for 'Packham's Triumph'.

The combination of girdling and P-Ca treatments should be investigated. If these two practices can complement each other, the combination will be a good agricultural tool to control vegetative growth, increase fruit size and improve return bloom.

In conclusion, it can be said that $\mathrm{P}-\mathrm{Ca}$ was effective in increasing fruit set and controlling shoot growth in most of the cultivars in this study, but it had a negative influence on fruit size. Girdling did not increase fruit set or reduce shoot growth but increased fruit size and return bloom in most of the cultivars. More trials are needed to optimise fruit production using these two vegetative growth control techniques and to determine how different cultivars react to these treatments. 


\section{Literature Cited}

Basak, A. and Rademacher, W. 2000. Growth regulation of pome and stone fruit trees by use of prohexanedione-Ca. Acta Hort. 514: 41-51.

Byers, E. and Yoder, K.S. 1999. Prohexadione-calcium inhibits apple, but not peach tree growth, but has little influence on apple fruit thinning or quality. HortScience 34(7): 1205-1209.

Costa, G., Andreotti, C., Bucchi, F., Sabatini, E., Bazzi, C., Malaguti, S. and Rademacher, W. 2001. Prohexadione-Ca (Apogee ${ }^{\circledR}$ ): Growth regulation and reduced fire blight incidence in pear. HortScience 36(5): 931-933.

Costa, G., Andreotti, C., Sabatini, E., Bregoli, A.M., Bucchi, F., Spada, G. and Mazzini, F. 2002. The effect of Prohexadione-Ca on vegetative and cropping performance and fire blight control of pear trees. Acta Hort. 596: 531-534.

Cowan, A.K., Cripps, R.F., Richings, E.W. and Taylor, N.J. 2001. Fruit size: towards an understanding of the metabolic control of fruit growth using avocado as a model system. Physiologia Plantarium 111(2):127-136.

Elfving, D.C., Sugar, D. and Faubion, D. 2002. Pear tree shoot growth patterns in relation to chemical control of vegetative growth with Prohexadione-Ca (Apogee $\left.{ }^{\mathbb{B}}\right)$. Acta Hort. 596: 711-716.

Elfving, D.C., Lombardini, L., McFerson, J.R., Drake, S.R., Faubion, D.F., Auvil, T.D., Van Ee, G. and Visser D.B. 2003. Effects of directed applications of ProhexadioneCalcium to tops of mature pear trees on shoot growth, light penetration pruning and fruit quality. Journal American Pomological Society 57(2): 45-57.

Evans, J.R., Evans, R.R., Regusci, C.L. and Rademacher, W. 1999. Mode of action, metabolism, and uptake of BAS 125W, Prohexadione-calcium. HortScience 34(7): 1200-1201.

Forshey, C.G. and Elfving, D.C. 1989. The relationship between vegetative growth and fruiting in apple trees. Hort. Rev. 11:229-287.

Greene, D.W. 1999. Tree growth management and fruit quality of apple trees treated with prohexadione-calcium (BAS 125). HortScience 34(7): 1209-1212.

Ingels, C. 2002. Effects of trunk girdling on tree growth, fruit production and fire blight. Acta Hort. 596: 641-642.

Miller, S.S. 2002. Prohexadione-calcium controls vegetative shoot growth in apple. Journal of fruit tree production 3(1): 11-28.

Miller, S.S. and Tworkoski, T. 2003. Regulating vegetative growth in deciduous fruit trees. PGRSA Quarterly 31(1): 8-46.

Owens, C.L. and Stover, E. 1999. Vegetative growth and flowering of young apple trees in response to Prohaxadione-calcium. HortScience 34(7): 1194-1196.

Smit, M. 2002. Shoot growth control of pear trees (Pyrus communis L.) with Prohexadione-Ca, M.Sc. Thesis, University of Stellenbosch, Stellenbosch.

Sugar, D., Elfving, D.C. and Mielke, E.A. 2002. Effects of Prohexadione-Ca (Apogee ${ }^{\mathrm{TM}}$ ) on blossoming, production and fruit quality in pear. Acta Hort. 596: 757-760.

Theron, K.I., Le Grange, M., Smit, M., Reynolds, S. and Jacobs, G. 2002. Controlling vigour and colour development in the bi-coloured pear cultivar Rosemarie. Acta Hort. 596: 753-756.

Unrath, C.R. 1999. Prohexadione-Ca: A promising chemical for controlling vegetative growth of apples. HortScience 34(7): 1197-1200.

Williams, M.W. 1984. Use of bio-regulators to control vegetative growth of fruit trees and improve fruiting efficiency. Acta Hort. 146: 97-104.

Wilton, J. 2000. Girdling studies. Orchardist 73 (10): 14-17.

Yamaquchi. M., Haji, T., Miyake M. and Yaegaki, H. 2002. Varietal difference in cell division and enlargement periods during peach (Prunus persica Batsch) fruit development. J. of Japanese Soc. for Hort. Sci. 71(2):155-163. 


\section{Tables}

Table 1. Summary of orchard detail of five cultivars used in trial.

\begin{tabular}{|c|c|c|c|c|c|}
\hline Parameter & $\begin{array}{l}\text { Early Bon } \\
\text { Chretien }\end{array}$ & Rosemarie & Flamingo & Forelle & $\begin{array}{l}\text { Packham's } \\
\text { Triumph }\end{array}$ \\
\hline Rootstock & BP3 & BP3 & BP3 & BP1 & Seedling \\
\hline Plant year & 1997 & 1994 & 1997 & 1993 & 1984 \\
\hline Spacing & $4 \times 1.5 \mathrm{~m}$ & $4.5 \times 1.5 \mathrm{~m}$ & $4.5 \times 1.75 \mathrm{~m}$ & $4.5 \times 1.5 \mathrm{~m}$ & $4.57 \times 2 \mathrm{~m}$ \\
\hline Cross pollination & Bouquets & Bouquets & Bouquets & $\mathrm{EBC}(10 \%)$ & $* *$ \\
\hline Full bloom date & 11 Sept 2002 & 18 Sept 2002 & 12 Sept 2002 & 13 Sept 2002 & 25 Sept 2002 \\
\hline Fruit thinning date* & 21 Oct 2002 & 31 Oct 2002 & 21 Oct 2002 & 21 Oct 2002 & None \\
\hline $\begin{array}{l}\text { Harvest date } \\
\text { Previous yields: }\end{array}$ & 6 Jan 2003 & 9 Jan 2003 & 13 Jan 2003 & 24 Feb 2003 & 12 Feb 2003 \\
\hline 2002 & 26 ton $/ \mathrm{ha}$ & 40 ton $/ \mathrm{ha}$ & 12 ton $/ \mathrm{ha}$ & 25 ton $/ \mathrm{ha}$ & 82 ton $/$ ha \\
\hline 2003 & 41 ton/ha & 36 ton/ha & 19 ton/ha & 36 ton/ha & 49 ton/ha \\
\hline
\end{tabular}

* Hand thinning according to commercial standards

** Clapps Favourite and Winter Nelis grafts on every $10^{\text {th }}$ tree

Table 2. Summary of prohexadione-calcium treatments applied to 'Early Bon Chretien', 'Rosemarie', 'Flamingo', 'Forelle' and 'Packham's Triumph' trees.

\begin{tabular}{lc}
\hline P-Ca concentration & Time of application (Total amount applied) \\
\hline Control & - \\
Girdled & 2 weeks after full bloom ${ }^{1}$ \\
$125 \mathrm{mg} \cdot \mathrm{l}^{-1}$ & $5-10 \mathrm{~cm}$ shoot growth \\
$2 \times 125 \mathrm{mg} \cdot \mathrm{l}^{-1}$ & $5-10 \mathrm{~cm}$ shoot growth +4 weeks later $^{3}$ \\
$250 \mathrm{mg} \cdot \mathrm{l}^{-1}$ & $5-10 \mathrm{~cm} \mathrm{shoot} \mathrm{growth}^{2}$ \\
\hline
\end{tabular}

${ }^{1}$ At petal drop in the case of 'Packham's Triumph'

${ }^{2}$ At petal drop in the case of 'Rosemarie'

${ }^{3} 3$ weeks later in the case of 'Packham's Triumph'

Table 3. The effect of girdling and prohexadione-calcium applied at different rates on the shoot growth of 'Early Bon Chretien', 'Rosemarie', 'Flamingo', 'Packham's Triumph' and 'Forelle' pears at La Plaisante Estate, Wolseley.

\begin{tabular}{lccccc}
\hline & \multicolumn{4}{c}{ Shoot growth $(\mathrm{cm})$} \\
\hline Treatments & Rosemarie & Early BC & Flamingo & $\begin{array}{c}\text { Packham's } \\
\text { Triumph }\end{array}$ & Forelle \\
\hline Control & $25.71 \mathrm{a}$ & $31.47 \mathrm{ab}$ & $55.78 \mathrm{a}$ & $34.82 \mathrm{a}$ & $61.65 \mathrm{a}$ \\
Girdled & $25.95 \mathrm{a}$ & $35.04 \mathrm{a}$ & $54.67 \mathrm{a}$ & $33.90 \mathrm{a}$ & $58.44 \mathrm{~b}$ \\
$1 \times 125 \mathrm{mg} . \mathrm{l}^{-1} \mathrm{P}-\mathrm{Ca}$ & $20.94 \mathrm{~b}$ & $28.97 \mathrm{~b}$ & $40.24 \mathrm{~b}$ & $24.20 \mathrm{~b}$ & $57.23 \mathrm{bc}$ \\
$2 \times 125 \mathrm{mg} . \mathrm{l}^{-1} \mathrm{P}-\mathrm{Ca}$ & $21.37 \mathrm{~b}$ & $28.04 \mathrm{~b}$ & $31.73 \mathrm{c}$ & $21.72 \mathrm{bc}$ & $53.53 \mathrm{c}$ \\
$1 \times 250 \mathrm{mg} . \mathrm{l}^{-1} \mathrm{P}-\mathrm{Ca}$ & $21.33 \mathrm{~b}$ & $21.82 \mathrm{c}$ & $36.10 \mathrm{bc}$ & $18.86 \mathrm{c}$ & $56.57 \mathrm{bc}$ \\
\hline Significance level & & & & & \\
$\quad$ Trt & 0.0050 & 0.0001 & 0.0001 & 0.0001 & 0.0014 \\
Control vs P-Ca & 0.0025 & 0.0030 & 0.0001 & 0.0001 & 0.0001 \\
\hline
\end{tabular}


Table 4. The effect of girdling and prohexadione-calcium applied at different rates on the fruit set of 'Rosemarie', Early Bon Chretien' and 'Forelle' pears.

\begin{tabular}{|c|c|c|c|}
\hline \multirow[t]{2}{*}{ Treatments } & \multicolumn{3}{|c|}{ Fruit thinned by hand per tree (no) } \\
\hline & Rosemarie & Early Bon Chretien & Forelle \\
\hline Control & $66.7 \mathrm{~cd}$ & $68.5 \mathrm{c}$ & $311.7 \mathrm{a}$ \\
\hline Girdled & $55.8 \mathrm{~d}$ & $58.5 \mathrm{c}$ & $324.9 \mathrm{a}$ \\
\hline $1 \times 125 \mathrm{mg} . \mathrm{l}^{-1} \mathrm{P}-$ & $129.7 \mathrm{ab}$ & $78.36 \mathrm{bc}$ & $374.8 \mathrm{a}$ \\
\hline $\mathrm{Ca}$ & $108.9 \mathrm{bc}$ & $105.0 \mathrm{ab}$ & $364.7 \mathrm{a}$ \\
\hline $\begin{array}{l}2 \times 125 \mathrm{mg} \cdot \mathrm{l}^{-1} \mathrm{P}- \\
\mathrm{Ca}\end{array}$ & $161.4 \mathrm{a}$ & $121.50 \mathrm{a}$ & $375.3 a$ \\
\hline $1 \times 250 \mathrm{mg} \cdot \mathrm{l}^{-1} \mathrm{P}-$ & 0.0001 & 0.0021 & 0.4276 \\
\hline $\mathrm{Ca}$ & & & \\
\hline $\begin{array}{l}\text { Significance level } \\
\text { Trt } \\
\text { Control vs P-Ca }\end{array}$ & 0.0004 & 0.0175 & 0.0932 \\
\hline
\end{tabular}

Table 5. The effect of girdling and prohexadione-calcium applied at different rates on average fruit weight at harvest of 'Rosemarie', 'Flamingo' and 'Packham's Triumph'.

\begin{tabular}{lccc}
\hline & \multicolumn{3}{c}{ Average fruit weight $(\mathrm{g})$} \\
\cline { 2 - 4 } Treatments & Rosemarie & Flamingo & Packham's Triumph \\
\hline Control & $132.62 \mathrm{a}$ & $158.00 \mathrm{~b}$ & $236.33 \mathrm{ab}$ \\
Girdled & $137.05 \mathrm{a}$ & $182.11 \mathrm{a}$ & $254.42 \mathrm{a}$ \\
$1 \times 125 \mathrm{mg} . \mathrm{l}^{-1}$ Prohexadione- & $115.54 \mathrm{~b}$ & $154.50 \mathrm{~b}$ & $234.38 \mathrm{ab}$ \\
$\mathrm{Ca}$ & $112.33 \mathrm{~b}$ & $148.78 \mathrm{~b}$ & $227.91 \mathrm{bc}$ \\
$2 \times 125 \mathrm{mg} .1^{-1}$ Prohexadione- & $107.23 \mathrm{~b}$ & $152.11 \mathrm{~b}$ & $210.84 \mathrm{c}$ \\
$\mathrm{Ca}$ & 0.0001 & 0.0001 & 0.0109 \\
$1 \times 250 \mathrm{mg} .1^{-1}$ Prohexadione- & & & \\
Ca & & & \\
Significance level & & & \\
$\quad$ Trt & & & \\
$\quad$ Control vs. P-Ca & 0.0001 & & \\
\hline
\end{tabular}

Table 6. The effect of girdling and prohexadione-calcium applied at different rates on the return bloom (reproductive buds / (reproductive buds + vegetative buds) $\times 100$ ) of 'Early Bon Chretien', 'Rosemarie', 'Flamingo', 'Packham's Triumph' and 'Forelle' pears at La Plaisante Estate, Wolseley.

\begin{tabular}{|c|c|c|c|c|c|}
\hline & \multicolumn{5}{|c|}{ Reproductive buds (\%) } \\
\hline Treatments & Rosemarie & Early BC & Flamingo & $\begin{array}{l}\text { Packham's } \\
\text { Triumph }\end{array}$ & Forelle \\
\hline Control & $46.90 \mathrm{~b}$ & $29.69 \mathrm{bc}$ & $35.56 \mathrm{~b}$ & $29.93 \mathrm{ab}$ & $15.28 \mathrm{~b}$ \\
\hline Girdled & $57.20 \mathrm{a}$ & $44.93 \mathrm{a}$ & $53.06 \mathrm{a}$ & $30.87 \mathrm{a}$ & $32.32 \mathrm{a}$ \\
\hline $1 \times 125 \mathrm{mg} \cdot \mathrm{l}^{-1} \mathrm{P}-\mathrm{Ca}$ & $46.33 \mathrm{~b}$ & $30.69 \mathrm{~b}$ & $36.32 \mathrm{~b}$ & $23.16 \mathrm{bc}$ & $8.24 \mathrm{bc}$ \\
\hline $2 \times 125 \mathrm{mg} \cdot \mathrm{l}^{-1} \mathrm{P}-\mathrm{Ca}$ & $48.02 \mathrm{~b}$ & $32.07 \mathrm{~b}$ & $42.83 \mathrm{~b}$ & $13.08 \mathrm{c}$ & $6.53 \mathrm{c}$ \\
\hline $1>250 \mathrm{mg} \cdot \mathrm{l}^{-1} \mathrm{P}-\mathrm{Ca}$ & $48.49 \mathrm{~b}$ & $24.88 \mathrm{c}$ & $34.83 \mathrm{~b}$ & $20.76 \mathrm{c}$ & $9.64 \mathrm{bc}$ \\
\hline Significance level & & & & & \\
\hline Trt & 0.0114 & 0.0001 & 0.0033 & 0.0001 & 0.0001 \\
\hline Control vs P-Ca & 0.7874 & 0.8378 & 0.5448 & 0.0004 & 0.0201 \\
\hline
\end{tabular}


Figures

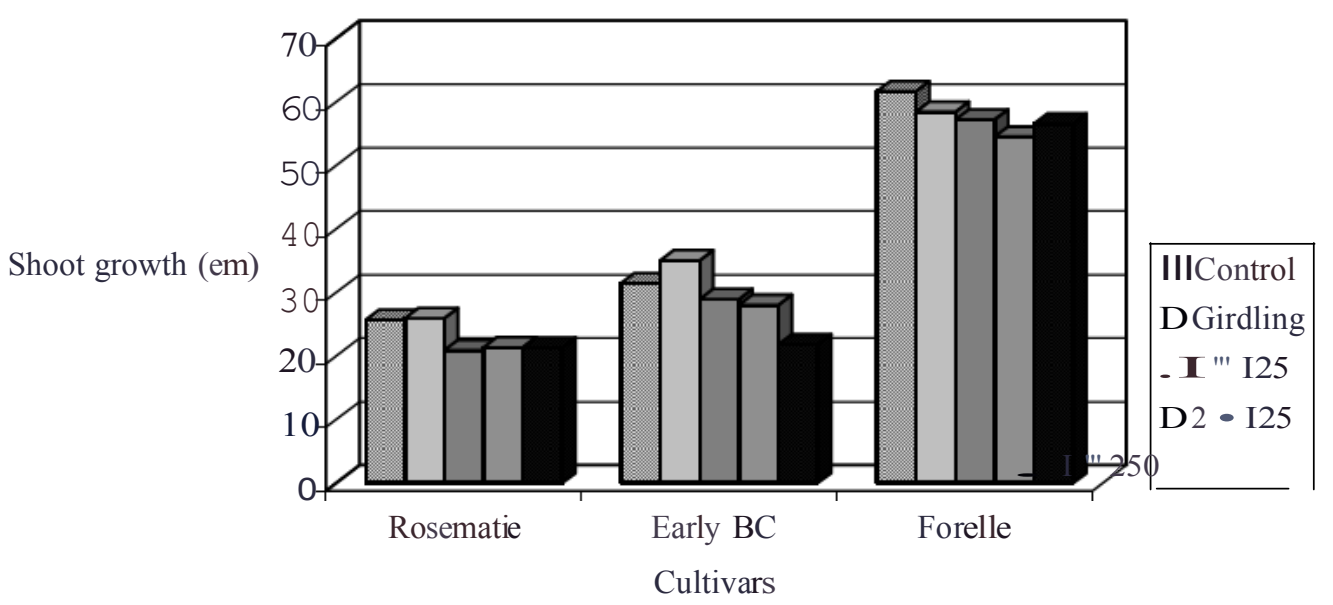

Fig. 1. The effect of different rates of P- $\mathrm{Ca}$ on the fmal shoot length of different pear cultivars. 